\title{
MAKALAH KEWIRAUSAHAAN
}

\section{MANAJEMEN SUMBER DAYA MANUSIA (SDM)}

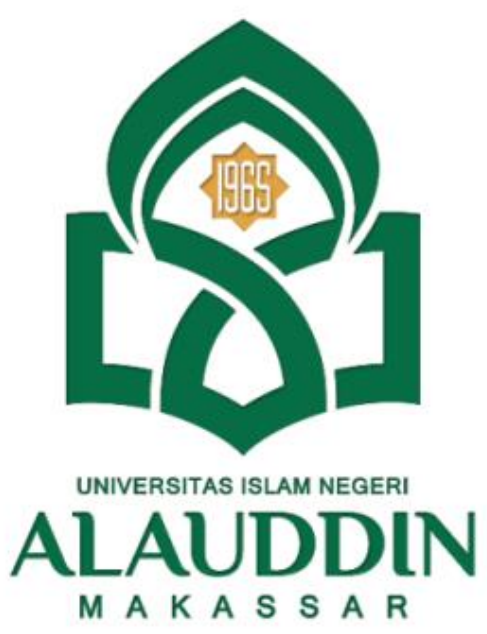

Dosen Pengampuh:

Dra. Hj. Nuraeni Gani, M.M

Disusun Oleh :

Rahmadana

90500120025

PRODI PERBANKAN SYARIAH

FAKULTAS EKONOMI DAN BISNIS ISLAM

UNIVERSITAS ISLAM NEGERI ALAUDDIN MAKASSAR

$2021 / 2022$ 


\section{KATA PENGANTAR}

Assalamu'alaikum Warohmatullahi Wabarokatuh

Puji dan syukur saya panjatkan kehadirat Tuhan Yang Maha Esa karena berkat rahmat dan karunia-Nyalah hingga makalah yang berjudul "MANAJEMEN SUMBER DAYA MANUSIA" ini dapat saya selesaikan dengan cukup mudah dan sesuai dengan waktu yang telah ditentukan. Tanpa pertolongan-Nya mungkin saya tidak akan mampu menyelesaikan tepat pada waktunya. Makalah ini saya buat untuk memenuhi tugas dari mata kuliah Kewirausahaan.

Saya mengucapkan terima kasih kepada ibu Dra. Hj. Nuraeni Gani, M.M selaku Dosen Kewirausahaan program studi Perbankan Syariah. Yang telah memberikan arahan dalam menyusun makalah ini. Semoga makalah ini dapat memberikan wawasan yang lebih luas kepada pembaca. Saya menyadari bahwa makalah ini masih kurang sempurna. Oleh karena itu, saya mengharapkan kritik dan saran yang membangun dari para pembaca. Terima Kasih.

Wassalamu'alakum Warohmatullahi Wabarokatuh.

Gowa, 21 November 2021

Penulis, 


\section{DAFTAR ISI}

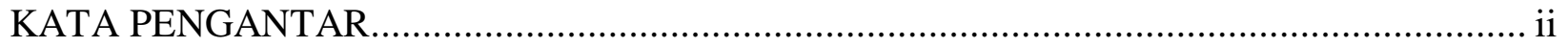

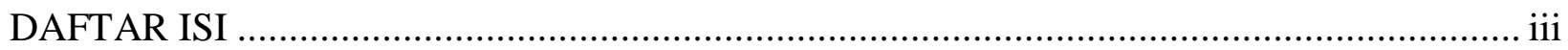

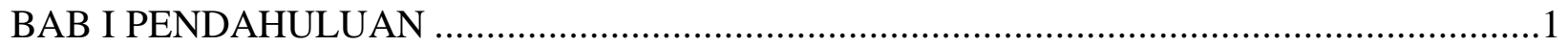

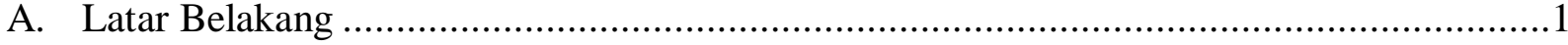

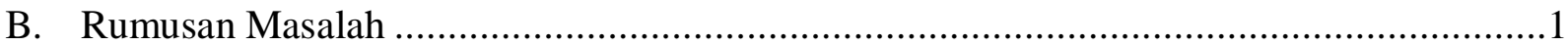

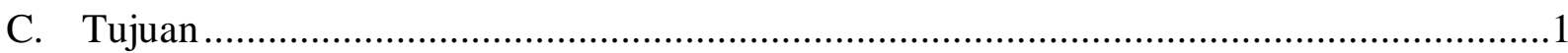

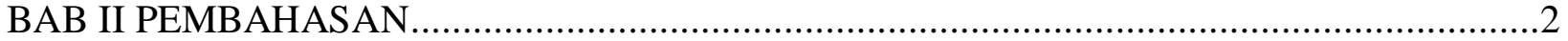

A. Pengertian Manajemen Sumber Daya Manusia (SDM) ..........................................2

B. Fungsi Manajemen Sumber Daya Manusia ..............................................................

C. Keunggulan Manajemen Sumber Daya Manusia .....................................................5

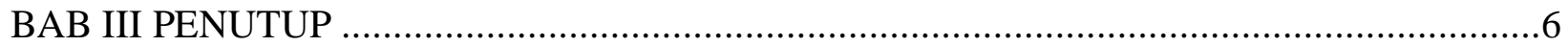

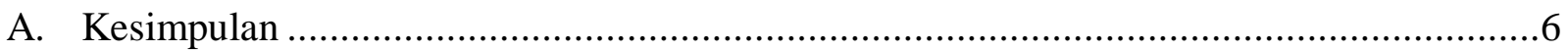

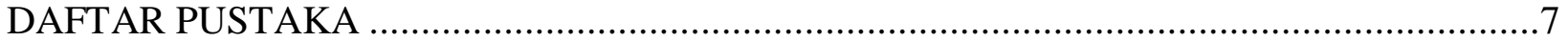




\section{BAB I \\ PENDAHULUAN}

\section{A. Latar Belakang}

Salah satu aspek yang tidak kalah pentingnya untuk dikelola para wirausahawan adalah sumber daya manusia (SDM) yang dimilikinya. Manusia (karyawan) yang menjadi motor penggerak kegiatan usaha perlu dikelola secara professional. Pengelolaan sumber daya manusia (SDM) ini biasanya dikenal dengan manajemen sumber daya manusia.

Pengelolaan sumber daya manusia adalah merupakan aspek yang sangat penting dalam proses pendidikan secara umum. Oleh karena itu fungsi-fungsi dalam pengelolaan sumber daya manusia harus dilaksanakan secara optimal sehingga kebutuhan yang menyangkut tujuan individu, perusahaan, organisasi ataupun kelembagaan dapat tercapai. Disamping itu dengan prosedur pengelolaan sumber daya manusia yang baik diharapkan kekurangan dan problem yang dihadapi oleh bangsa Indonesia, yaitu yang terkait dengan kemampuan daya saing dapat teratasi.

\section{B. Rumusan Masalah}

1. Apa pengertian manajemen sumber daya manusia?

2. Bagaimana fungsi manajemen sumber daya manusia?

3. Apa keunggulan manajemen sumber daya manusia?

\section{Tujuan}

1. Untuk mengetahui pengertian manajemen sumber daya manusia

2. Untuk mengetahui fungsi manajemen sumber daya manusia

3. Untuk mengetahui keunggulan manajemen sumber daya manusia 


\section{BAB II \\ PEMBAHASAN}

\section{A. Pengertian Manajemen Sumber Daya Manusia (SDM)}

Bagi suatu organisasi, manajemen sumber daya manusia menyangkut keseluruhan urusan manusia dalam organisasi untuk ikut berperan aktif dalam pencapaian tujuan yang telah ditetapkan. Pengelolaan sumber daya manusia merupakan suatu proses yang berhubungan dengan implementasi fungsifungsi manajemen mulai dari perencanaan, pengorganisasian, pengarahaan hingga pengawasan yang berperan penting secara efektif dan efisien dalam menunjang tercapainya tujuan individu, maupun organisasi. Oleh karenanya, apabila sumber daya manusia dalam organisasi dikelola dan dimanfaatkan dengan baik, maka organisasi tersebut akan mampu menjalankan roda usahanya secara optimal. Proses pengelolaan manusia dalam organisasi ditangani oleh bagian manajemen sumber daya manusia yang memiliki fungsi strategis dan berperan dalam meningkatkan keefektifitasan dan efisiensi sebuah organisasi dalam mengelola manusia yang ada di dalamnya.

Manajemen sumber daya manusia dapat didefinisikan sebagai pendekatan strategis untuk pengelolaan asset yang paling berharga di dalam organisasi yaitu orang yang bekerja di sana, yang secara individu atau kolektif (tim kerja) berkontribusi terhadap pencapaian sasaran yang telah ditetapkan . Di sini ditekankan pada pengelolaan manusia tidak saja menjadi tugas para manajer dalam menetapkan tujuan strategis tetapi juga diharapkan peran serta dari karyawan untuk ikut termotivasi meningkatkan diri demi pencapain tujuan bersama.

Manajemen sumber daya manusia diartikan pula sebagai suatu proses perencanaan, pengorganisasian, pengarahan dan pengawasan kegiatan-kegiatan pengadaan, pengembangan, pemberian kompensasi, pengintegrasian, pemeliharaan dan pelepasan sumber daya manusia agar tercapai berbagai tujuan individu, organisasi dan masyarakat. Atau dapat dikatakan bahwa manajemen sumber daya manusia merupakan suatu proses yang terdiri dari serangkaian kegiatan di mana yang satu dan lainnya saling berhubungan mulai dari perencanaan, pengelolaan hingga pengawasan terhadap sumber daya manusia yang dimiliki. Untuk itu manajemen sumber daya manusia harus dipandang tidak hanya sebagai proses pegelolaan manusia secara tradisional namun harus dilakukan 
proses pengelolaan secara strategik dan memandangnya sebagai asset berharga yang perlu dikembangkan.

Kegiatan manajemen sumber daya manusia dipandang memiliki sifat proaktif dan strategis meliputi sistem yang lebih luas, yang memperlakukan tenaga kerja sebagai asset bukan sebagai biaya, lebih berorientasi pada tujuan pada hasil serta berfokus pada komitmen kerja mereka5 . Semua hal tersebut menunjukkan bahwa manajemen sumber daya manusia lebih menekankan strategi dan perencanaan dari pada kegiatan administratif dan operasional saja. Manajemen sumber daya manusia mempunyai fokus strategis dan besinergi dengan semua kebijakan bisnis organisasi serta menjadi partner usaha yang memberikan solusi pada setiap masalah yang dihadapi organisasi.

\section{B. Fungsi Manajemen Sumber Daya Manusia}

Manajemen sumber daya manusia memiliki fungsi penting bagi organisasi, tidak saja pada level manajerial tetapi juga pada tingkat operasional. (Sunyoto 2012) menyebutkan bahwa kedua fungsi tersebut memiliki landasan kuat untuk bahan pijakan pada penerapan atau praktik yang diterapkan dalam organisasi. Fungsi-fungsi dimaksud diuraikan sebagai berikut:

a. Fungsi manajerial, dibagi menjadi empat yaitu perencanaan, pengorganisasian, pengarahan dan pengendalian.

1. Perencanaan, meliputi penentuan program pengelolaan sumber daya manusia yang akan membantu pencapaian tujuan organisasi. Fungsi ini merupakan fungsi yang paling esensial karena menyangkut rencana dari awal pengelolaan baik dalam jangka pendek maupun jangka panjang yang berkaitan erat dengan operasional organisasi dan kelancaran kerja didalamnya.

2. Pengorganisasian; adalah membentuk organisasi dengan merancang susunan dari berbagai hubungan antar jabatan, jalannnya pekerjaan, aktivitas personalia dan faktor lainnya.

3. Pengarahan; adalah mengusahakan agar karyawan mau bekerja secara efektif melalui perintah, motivasi dan aturan yang mengikat.

4. Pengendalian; adalah mengadakan pengamatan atas pelaksanaan jalannya operasional kerja dan membandingkan dengan rencana, serta mengoreksinya 
apabila terjadi penyimpangan atau jika perlu menyesuaikan kembali rencana yang telah dibuat.

b. Fungsi operasional; dibagi manjadi enam aktivitas yaitu pengadaan, pengembangan, kompensasi, integrasi, pemeliharaan dan pemutusan hubungan kerja

1. Fungsi pengadaan meliputi aktivitas perencanaan sumber daya manusia, perekrutan, seleksi, penempatan dan orientasi karyawan, perencanaan mutu dan jumlah karyawan. Sedangkan perekrutan, seleksi dan penempatan berkaitan dengan penarikan, pemilihan, penyusunan dan evaluasi lamaran kerja, tes psikologi dan wawancara. Fungsi ini berguna untuk memperoleh jenis, komposisi dan jumlah sumber daya manusia tepat, yang diperlukan untuk mencapai sasaran organisasi.

2. Fungsi pengembangan bertujuan untuk meningkatkan keterampilan, pengetahuan dan sikap atau prilaku kerja karyawan agar dapat melaksanakan tugas dengan baik. Kegiatan ini menjadi semakin penting dengan berkembangnya dan semakin kompleksnya tugastugas manajer dalam program pengembangan karyawan. Fungsi ini berkaitan dengan peningkatan keterampilan dan kemampuan yang diupayakan melalui jalur pelatihan maupun pendidikan terhadap sumber daya manusia yang dimiliki, juga berbagai bentuk pengembangan diri untuk para karyawan yang berprestasi.

3. Fungsi kompensasi dapat diartikan sebagai pemberian penghargaan yang adil dan layak kepada karyawan sebagai balas jasa kerja mereka. Pemberian kompensasi merupakan tugas yang paling kompleks dan juga merupakan salah satu aspek yang paling berarti bagi karyawan maupun organisasi.

4. Fungsi pengintegrasian karyawan ini meliputi usahausaha untuk menyelaraskan kepentingan individu karyawan, organisasi dan masyarakat. Usaha itu perlu memahami sikap dan perasaan karyawan untuk dipertimbangkan dalam pengambilan keputusan.

5. Fungsi pemeliharaan tidak hanya mengenai usaha untuk mencegah kehilangan karyawan karena berhenti tetapi dimaksud untuk memelihara sikap kerja sama dan kemampuan bekerja karyawan tersebut. Fungsi ini berkaitan dengan upaya 
mempertahankan kemauan dan kemampuan kerja karyawan melalui penerapan beberapa program yang dapat meningkatkan loyalitas dan kebanggaan kerja.

6. Pemutusan hubungan kerja yaitu memutuskan hubungan kerja dengan karyawan dan mengembalikannya kepada masyarakat. Proses pemutusan hubungan kerja yang utama adalah pensiun, pemberhentian, pengunduran diri dan pemecatan.

\section{Keunggulan Manajemen Sumber Daya Manusia}

Manajemen sumber daya manusia merupakan bagian dari ilmu manajemen yang memfokuskan perhatian pada pengaturan peranan sumber daya manusia dalam organisasi. Bidang ini memiliki peranan penting untuk keberhasilan organisasi mengingat di dalamnya ada modal manusia yang perlu diperhatikan dengan kualitas berharga yang dimilikinya. Dalam hal strategi, organisasi dapat berhasil apabila memiliki keunggulan kompetitif yang berkelanjutan. Oleh karena itu, organisasi membutuhkan jenis sumber daya yang akan memberi mereka keuntungan tersebut. Keunggulan sumber daya manusia memiliki kualitas yang diperlukan organisasi karena sumber daya manusia memiliki keunggulan lebih dibandingkan sumber daya lainnya. Keunggulan yang dimiliki sumber daya manusia meliputi berharga, tidak dapat ditiru, dan tidak dapat digantikan

1. Sumber daya manusia berharga (human resources are valuable). Karyawan berkualitas tinggi akan menyediakan layanan yang maksimal, layanan yang diberikan akan mempengaruhi kepuasan pelanggan dan mendatangkan pelanggan baru, sehingga karyawan yang berkualitas sangat berharga bagi keberlanjutan dan perkembangan organisasi.

2. Sumber daya manusia tidak dapat ditiru (human resources are rare). Sumber daya manusia yang memiliki kemampuan, kompeten dan keahlian tinggi sulit untuk ditiru oleh pesaing. Untuk itu proses rekrutmen dan seleksi membawa peranan dalam mendapatkan karyawan yang memiliki kemampuan khusus tersebut.

3. Sumber daya manusia tidak dapat digantikan (human resources have no substitutes). Ketika orang-orang mendapatkan pelatihan yang baik, memiliki motivasi tinggi, mau belajar, mengembangkan kemampuan, dan memberi layanan maksimal kepada pelanggan maka karyawan tersebut perlu dipertahankan. Karyawan yang berkomitmen dan berbakat tidak akan bisa digantikan, setiap orang memiliki keunikan dan tidak dapat disamai dengan sesamanya (Suryani and Foeh 2019 ). 


\section{BAB III \\ PENUTUP}

\section{A. Kesimpulan}

Berdasarkan rumusan dan hasil pembahasan dari makalah ini, maka dapat ditarik kesimpulan sebagai berikut:

1. Manajemen sumber daya manusia diartikan pula sebagai suatu proses perencanaan, pengorganisasian, pengarahan dan pengawasan kegiatan-kegiatan pengadaan, pengembangan, pemberian kompensasi, pengintegrasian, pemeliharaan dan pelepasan sumber daya manusia agar tercapai berbagai tujuan individu, organisasi dan masyarakat.

2. Fungsi manajemen sumber daya manusia dibagi menjadi dua, yaitu fungsi manajerial dan fungsi operasional.

3. Manajemen sumber daya manusia memiliki peran yang sangat penting, dimana manajemen sumber daya manusia memiliki keunngulan berupa sumber daya manusia meliputi berharga, tidak dapat ditiru, dan tidak dapat digantikan, 


\section{DAFTAR PUSTAKA}

Sunyoto, Danang. Kuesioner dan Analisis Data Sumber Daya Manusia (Praktik Penelitian). Yokyakarta: Center for Academic Publishing Services, 2012.

Suryani, Ni Kadek, and John Foeh. Manajemen Sumber Daya Manusia Tinjauan Praktis Aplikatif. Bandung: Nilacakra, 2019 . 